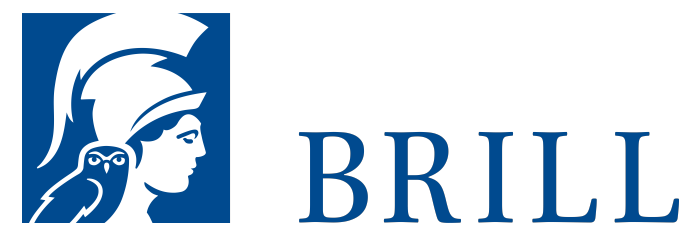

\title{
Hoffnung als Sinn für Möglichkeit und Unverfügbarkeit
}

\author{
Kontrapunkte zur Philosophie der Lebenskunst
}

Author: Christiane Borchel

Thema des Buches ist die Bedeutung von Hoffnung für das Leben von Menschen. Grundlegende Defizite der Philosophie der Lebenskunst werden herausgearbeitet: Zum einen verengt die Lebenskunstphilosophie den für sie charakteristischen Kunst bzw. Ästhetikbezug ihrer foucaultschen Tradition entsprechend stark auf den Aspekt der Macht bzw. der Selbstmächtigkeit. Zum anderen neigt sie mit dieser Fokussierung dazu, Forderungen des ökonomisch geprägten Zeitgeistes unreflektiert zu übernehmen. Die Grenzen der Selbstmächtigkeit geraten aus dem Blick. In Auseinandersetzung mit der Philosophiegeschichte des Hoffnungsbegriffs wird deutlich, dass Hoffnung immer wieder als etwas beschrieben worden ist, das auf etwas der Verfügbarkeit Entzogenes gerichtet ist. Zugleich ist Hoffnung oft ein hoher Wert beigemessen worden. An diese Einsichten anknüpfend wird im letzten Teil systematisch ausgeführt, was Hoffnung ist, welche Formen sie annehmen kann und was sie wertvoll macht. Unter anderem kann Hoffnung die Form einer Haltung annehmen, die der Verzweiflung und der Vermessenheit entgegengesetzt ist. Immer ist mit Hoffnung die Einsicht verbunden, dass die eigene Handlungsmacht begrenzt ist.

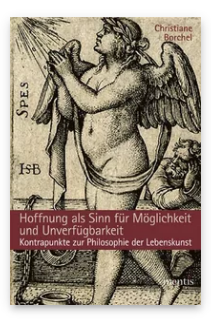

Pages: 206

Seiten

Language:

German

Subjects:

General,

Philosophy

Publisher: Brill | mentis

E-Book (PDF)

Released online:

o1 Oct 2014

ISBN: 978-3-

95743-985-7

List price

Paperback

Publication date:

o1 Oct 2014

ISBN: 978-3-

89785-072-9

List price 
For more information see brill.com

Order information: Order online at brill.com +44330 333 0049 | customerservices@brill.com Submission information: brill.com/authors

Titles published by Brill | Fink, Brill | mentis or Brill | Schöningh: +49(o)715413279216| brill@brocom.de 